Marijana Ćurak*

Sandra Pepur**

Dujam Kovač $\check{\check{c}}^{* * *}$
JEL Classification: D81, G22, G52, G53. Original scientific paper https://doi.org/10.32910/ep.71.4.3

\title{
DOES FINANCIAL LITERACY MAKE THE DIFFERENCE IN NON-LIFE INSURANCE DEMAND AMONG EUROPEAN COUNTRIES?
}

While risk aversion and affordability of insurance are considered as the most important determinants of non-life insurance demand, understanding and knowledge of complex non-life insurance products are less researched. Studies on insurance demand conducted at the cross-section level, which include education, usually use it as a proxy for risk aversion and to a limited extent as a measure of financial literacy. Moreover, the general level of education does not accurately reflect the level of understanding of sophisticated insurance instruments. Consequently, the main aim of this research is to analyse the impact of financial literacy on the demand for non-life insurance by applying a more precise measure of financial literacy. The empirical analysis is based on the dataset of 38 European countries in the period from 2010 to 2016 and is done using the panel data analysis technique. Research findings confirm that financial literacy makes the difference in non-life insurance demand among European countries, while controlling for other economic, social/cultural, market structure and institutional determinants of non-life insurance demand. The paper contributes to the literature on non-life in-

* Marijana Ćurak, PhD, Professor, University of Split, Faculty of Economics, Business and Tourism (e-mail: marijana.curak@efst.hr).

** Sandra Pepur, PhD, Assistant Professor, University of Split, Faculty of Economics, Business and Tourism (e-mail: sandra.pepur@efst.hr).

*** Dujam Kovač, mag. oec., Research Teaching Assistant, University of Split, Faculty of Economics, Business and Tourism (e-mail: dujam.kovac@efst.hr). The paper was received on 12.06.2019. It was accepted for publication on 11.02.2020. 
surance demand, especially the one on the relationship between financial literacy and the demand for non-life insurance.

Key words: Financial literacy, non-life insurance demand, European countries

\section{Introduction}

Non-life insurance is one of the most important methods for managing property and liability risks. According to the existing studies, various economic, social/ cultural, market structure as well as institutional factors influence the demand for non-life insurance products (for the literature review see Feyen, Lester, and Rocha, 2011; Eling, Pradhan, and Schmit, 2013; and Outreville, 2013). Risk aversion and affordability of insurance are usually stated as the most important factors that encourage people to transfer risks to insurance companies. However, beside the attitude to risk and the ability to pay for risk transfer and other important determinants of making the decision to buy insurance, there is the question on people's awareness of risk exposure as well as on their knowledge of the available mechanisms of risk management in terms of both benefits and costs. These factors refer to financial literacy.

Financial literacy is related to an individual's specific abilities to process financial information and make efficient decisions in the context of personal finance management. Precisely, it refers to the knowledge and understanding of important aspects of personal finance, such as investing, insurance, pension, and taxes, and the ability to apply that knowledge to financial decision-making. Financially literate individuals have more knowledge on risk, risk management tools, benefits and costs of insurance and they are capable to make efficient decisions on risk management and, thus, decide to buy insurance. Although it is usually stated that financial illiteracy could result in underinsurance, according to the model of Kubitza, Hofmann, and Steinorth (2019) inefficient risk management decisions, which are a consequence of financial illiteracy, could also refer to overinsurance.

While there is an increasing number of studies on the importance of financial literacy in making financial decisions, especially in the field of investments and saving for retirement, research on the impact of financial literacy on insurance demand is rare as stated by Lin, Bruhn, and William (2019) and Kubitza et al. (2019). However, insurance is an important tool for risk management and it is a part of individuals' financial planning, especially in developed countries. In Western European countries, the average spending on life insurance was $\$ 1,537.7$ and on non-life insurance $\$ 1,030.4$ in 2017. On the other hand, in Central and Eastern 
Europe the average life insurance density was $\$ 58.1$ and the non-life one $\$ 73.2$ (Swiss Re, 2018). Additionally, non-life insurance is very heterogeneous since it covers various types of risks. Thus, it is expected that information on risk and risk understanding, insurance terms, and insurers' financial position are important prerequisites for making a decision on buying insurance.

In comparison to research on the effect of financial literacy on life insurance demand as well as on the determinants of life insurance consumption in general, research of factors of non-life insurance demand, including financial literacy, is scarce (Eling et al., 2013 and Outreville, 2013). Most studies are performed at micro-level, while those at cross-country level include financial literacy to a very limited extent and commonly apply general education as a measure of some aspects of financial literacy. Strictly speaking, only in some cases education is used to express risk awareness while most of the studies that include general education usually use it as a proxy of risk aversion. However, the general level of education (secondary or tertiary education) does not accurately reflect financial literacy. According to Treerattanapun (2011, p. 10) "tertiary education may not be a good proxy of one's understanding of sophisticated financial and insurance products as the knowledge of these products may not be taught in schools". Thus, when considering the determinants of insurance demand, "further study on both education and literacy is warranted" (Eling et al. 2013, p. 243). Finally, according to Insurance Europe (2017, p. 6) "improving financial literacy levels in Europe is an important societal challenge that requires contributions from a wide range of stakeholders." Therefore, the main aim of this research is to analyse the impact of financial literacy on the demand for non-life insurance, applying a more precisely proxy for the understanding and knowledge of non-life insurance products - the percentage of tertiary education graduates completing business, administration and law programmes. The research is based on the unbalanced panel dataset of 38 European countries in the period from 2010 to 2016.

According to the empirical results, financial literacy positively influences the demand for non-life insurance. The paper contributes to the literature in the field of non-life insurance demand in general, as it is less researched in comparison to life insurance demand. The research contributes to filling the gap in the literature on financial literacy in the context of insurance. Precisely, the main contribution of the study is the application of a more accurate measure of financial literacy, which, according to the authors' best knowledge, has not been applied in existing research on non-life insurance demand at the macro level.

The paper is structured as follows. Section 2 reviews literature on non-life insurance demand with a particular focus on financial literacy. The data and methodology are described in Section 3. The results are presented in Section 4, followed by conclusions in Section 5 . 


\section{Literature Review}

\subsection{Financial Literacy}

Financial literacy develops individual's specific abilities and responsible behaviour in managing personal finance. The recent global financial crisis has revealed how harmful a lack of individuals' financial education and skills and a low level of (risk) awareness can be. Although financial illiteracy did not cause the crisis, it definitely worsened the effects the crisis had on the lives of individuals, their families, and on the stability of entire national economies. The results of a research by the Organisation for Economic Co-operation and Development (OECD) on financial literacy show that over $80 \%$ of European citizens have chosen financial products without shopping around and without using independent information or advice. Over $40 \%$ of respondents in European countries have not even gathered information before choosing financial products (Insurance Europe, 2017, p. 7).

In the context of insurance, the aim of improving financial literacy primarily refers to developing knowledge about risk, increasing both risk awareness and the awareness of potential opportunities and benefits (Insurance Europe, 2017, p. $6)$. This aim is supported by the results of various studies that examine different aspects of financial literacy and which indicate that many individuals have a low level of risk awareness and challenges they face during their lifetime, as well as a lack of knowledge on how to manage these risks (e.g. through purchase of insurance products). A research performed in the U.S. shows that insurance literacy is low and is dominantly determined by an interest in personal finance and the confidence in insurance decision-making (Tennyson, 2011a). Additionally, when comparing insurance literacy among the insurance lines, individuals know less about property and liability insurance than about life and health insurance products (Tennyson, 2011b). A 2012 Eurobarometer survey on consumer behaviour when choosing insurance products shows that when buying non-life insurance products, such as motor, property or health insurance, $26 \%$ of respondents take the first product they come across - without comparing different offers/products of different insurers. In addition, $40 \%$ of respondents buy whichever life insurance product they come across first (Insurance Europe, 2017, p. 7-8). These results point to a considerable percentage of less informed customers who choose insurance products randomly. This is even more important in the light of the fact that insurance contracts are among the most utilized financial and risk management products - namely, car, life, and private health insurance are among the top six financial products and services that EU-28 citizens use (Special Eurobarometer 446,2016 , p. 4). A potential reason for illiteracy about insurance contracts is that 
insurance naturally pays out only in case of a loss, which is usually a low probability event (Kubitza et al., 2019). Therefore, the return on insurance seems less easy to evaluate than the returns on other financial products, such as, for example, equity investments. Additionally, according to some findings, individuals do not read their insurance contracts at all (Kubitza et al., 2019, p. 4). These observations further motivate our research on the influence of financial literacy on the demand for non-life insurance.

Among the variety of financial literacy definitions, the one from OECD is the most cited one in recent studies. According to OECD (2005), financial literacy is a combination of awareness, knowledge, skills, attitudes, and behaviours necessary to make sound financial decisions and ultimately achieve individual financial wellbeing. These attributes are developed and attained through the process of financial education. It can, therefore, be said that financial literacy is a measurable result of the efficiency and quality of financial education (Cvrlje, 2014, according to Barbic and Glasnović, 2018, p. 55). In this context, additional education on finance and risk contributes to raising an individual's awareness of risk, enhancing a better understanding of key features of insurance products and consequently recognizing and selecting a quality insurer, optimal level of insurance cover and/or a product that best suits the individual's expectations and needs. This is particularly evident nowadays when the diversity and complexity of insurance products and the amount of information about them is growing rapidly (Insurance Europe, p. 6). Lin et al. (2019) go further and define insurance literacy as the understanding of the concept of insurance, knowledge on risk as well as the ability to apply knowledge in making a decision on buying insurance.

Numerous challenges and global trends have transferred the responsibility for major financial decisions to individuals. In recent years, the governments of many countries have been reducing state-supported pensions and health care benefits and have been promoting policies of individual retirement accounts and private pension benefits (Jappelli, 2010, p. 431). In such circumstances, where risk is transferred from governments and companies (employers) to individuals, individuals become more responsible for their future and financial security and become subject to different risks that they have to manage on their own, i.e. revenue and investment risk. Additionally, demographic trends, such as longer life expectancy, put pressure on individuals to ensure adequate savings to cover longer period of retirement and longer period of using health care services by themselves and members of their families. Additionally, as a result of the development of technology and financial innovations, the availability and range of financial products and services have expanded. However, the complexity of these products and services has increased as well, making individuals' choices more difficult and risky, as information becomes more demanding. 
All the above-mentioned changes justify and support the importance of financial literacy development. A wide range of stakeholders (academic researchers, relevant ministries of states, central banks, financial services regulators, international institutions such as the World Bank and the OECD, etc.) have recognised the importance of financial education, the current low level of financial literacy and the challenges in the process of its improvement as well as the contributing role of different stakeholders in this process. They have agreed to take adequate measures, through formal and informal channels, to raise awareness of the importance of gaining specific skills and knowledge and to ensure their continuous promotion and improvement. To fulfil these goals, measuring financial literacy or designing an adequate measuring instrument is of high importance. In the scientific literature, the starting point and the most commonly used instrument are the questions from Lusardi and Mitchell $(2011,2014)$. The authors identified three economic concepts that individuals, in their opinion, should have some understanding of, if they were to use them when making financial decisions: interest compounding, inflation and risk diversification (Lusardi and Mitchell, 2011, p. 499). These three concepts ${ }^{1}$ have become a benchmark for measuring financial literacy (Lusardi and Mitchell, 2011, p. 499).

The OECD, World Bank and European Commission have had a major role in stimulating and developing financial literacy (Vehovec, 2011, p. 56). The OECD started its financial education project in 2003 through the International network for financial education OECD/INFE. A step forward in creating standardized questionnaires that would allow comparability of the level of financial literacy between countries was partly taken through the literacy study within the OECD's PISA project. Namely, the PISA survey tests high-school students in maths, reading and science and is conducted every three years. Since 2012, PISA tests have also examining the 15-year-old students' level of financial knowledge and their ability to apply knowledge and skills to particular situations. The database of the above-mentioned research, although extensive and to a certain degree harmonized at the international level, is not complete or available for a cross-country analysis, i.e. there is no continuous time series which is a precondition for the application of panel methodology.

Therefore, the effects of financial literacy on various aspects of financial behavior, such as purchasing insurance products, are explored through questionnaires targeting specific groups of respondents (students, adults, employed, etc.) within a country. However, in comparison to the literature on the importance of financial literacy for other aspects of personal finance decision making, existing research on

1 These three questions were initially designed to be included in an experimental financial literacy module for the study on United States households. 
financial literacy is less focused on insurance (Tennyson, 2011b). Moreover, these micro-level studies mainly focus on life insurance (see Hecht and Hanewald, 2010; Cappelletti, Guazzarotti, and Tommasino, 2013), long-term care insurance (see Gousia, 2016; Lin and Prince, 2016) and micro-insurance with inconclusive results (for a comprehensive literature review see Eling et al., 2014). However, this kind of "micro-level" research is not sufficient for a more comprehensive analysis and understanding of the processes in the insurance industry and the differences that occur in non-life insurance demand between the countries. In order to overcome the problem of missing data and in the same time fill the research gap on the non-life insurance demand determinants, the demographic attribute of financial literacy in most of the recent studies is approximated with the education level, namely the share of population with higher degree of education in the total population of the country. However, "investment in financial knowledge appears to be a specific form of human capital, rather than being simply associated with more years of schooling... general knowledge (education) and more specialized knowledge (financial literacy) both contribute to more informed financial decision making" (Lusardi and Mitchell, 2014, p. 23-24). Thus, the general level of education does not provide a good approximation of financial knowledge (Treerattanapun, 2011). Moreover, only in some of the insurance demand cross-country studies education is used for risk awareness and knowledge of insurance concepts, but is rather used more often as a proxy for risk aversion. ${ }^{2}$ However, these two risk concepts should be differentiated. Risk aversion is the attitude towards risk by individuals with concave expected utility function. Risk awareness means that the individual recognizes the existence of risk and, in accordance to the risk attitude, costs and other factors, he or she uses or does not use some of the risk management tools.

These difficulties and shortcomings in measuring financial literacy for the purpose of international comparisons could be the cause of inconclusive results of empirical research on the effect of financial literacy/education on insurance demand, which give the argument for additional examination of the effect of both education and literacy on insurance demand (Eling et al., 2013, p. 23). Consequently, in this research a new measure of financial literacy is applied and its effect on non-life insurance demand is analysed, while controlling for the influence of other factors that are usually included in the standard model of non-life insurance demand. They refer to various economic, social/cultural, market structure and institutional determinants for which a description of their effects on non-life insurance demand and the review of the related literature follow.

${ }^{2}$ For this reason, the education as a proxy of risk aversion is explained and the review of the related literature is given in the following subsection of the paper. 


\subsection{Economic, Social/Cultural, Market Structure and Institutional Determinants}

The existing empirical literature on non-life insurance demand at crosscountry level usually considers economic, socio-cultural, institutional and market structure factors that could influence the willingness of units exposed to risk to buy insurance.

At a higher level of income, non-life insurance is more affordable and people demand more insurance products. On the other hand, with a higher level of income, units exposed to risk will have the opportunity to take self-insurance and cover future losses by themselves. A positive effect of income on property-liability insurance is confirmed by Beenstock, Dickinson and Khajuria (1988); Outreville (1990); Esho, Kirievsky, Ward, and Zurbruegg (2004); Feyen et al. (2011); Elango and Jones (2011); Poposki, Kjosevski and Stojanovski (2015); Trinh, Nguyen, and Sgro (2016). Browne, Chung and Frees (2000) found that income positively influences both the demand for motor vehicle and general liability insurance having a stronger impact on motor insurance. Beside the absolute level of income, Dragos (2014) analyses the impact of distribution of income or inequality, measured by GINI index, on the demand for non-life insurance. According to the results, there is a negative relationship between income inequality and non-life insurance demand, suggesting that with a smaller degree of inequality, the demand for insurance increases.

A higher level of wealth implies more assets exposed to risk and consequently a higher demand for insurance. However, besides considering wealth as a loss potential, more wealth denotes more resources that could be used to cover losses. Thus, according to this perspective wealth serves as a substitute for insurance. Wealth is rarely analysed in cross-section empirical studies due to a lack of reliable data as well as its correlation with income (Feyen et al., 2011; Outreville, 2013). According to Browne et al. (2000), the demand for both general liability and motor vehicle insurance is negatively correlated with wealth, implying that wealth is a substitute for insurance. On the other hand, Kjosevski and Petkovski (2015) find positive effects of wealth, measured by the number of dwellings per 1,000 inhabitants, on the demand for non-life insurance.

It is expected that price is inversely related to the demand for property and liability insurance. Higher price implies higher cost of the coverage, which discourages people from buying insurance. Assuming that the price of insurance is higher in countries with lower level of economic liberalization, Browne et al. (2000) apply the share of foreign insurance companies in a market as a proxy for the price of insurance. They find a negative relationship between the participation of foreign 
insurers and the level of development of motor insurance, implying that markets with higher insurance prices are more attractive to foreign insurers in comparison to more competitive markets with lower insurance premiums. The opposite result is found in the case of general liability insurance, suggesting that foreign insurers encourage competition, which lowers premiums and increase the demand for insurance. The authors explain the contrasting results by the difference in technical ability required to underwrite these lines of insurance (Browne et al., 2000, p. 85). However, according to Esho et al. (2004) the participation of foreign insurers in domestic markets primarily indicates the market openness but not necessarily the efficiency of insurers. Consequently, the authors use inverse loss ratio (insurance premiums divided by claims) as a proxy of insurance price. The negative effect of the price on demand for non-life insurance is confirmed by the part of the results (those achieved by the GMM estimator). According to Marquis, Buntin, Escarce, Kapur and Yegian (2004), the price elasticity of the demand for insurance ranges from 0.2 to 0.4 .

Inflation is an indicator of monetary discipline. It reduces the amount of money that insurance companies pay in case of loss and negatively affects the demand for non-life insurance. Poposki et al. (2015) confirm the theoretical expectation of negative influence of inflation on non-life insurance. However, the findings of Feyen et al. (2011) are conflicting. The explanation of a positive effect of inflation on the demand for non-life insurance is that in an inflationary environment investors' focus changes from financial to real investment, which increases the demand for non-life insurance to cover the risk the asset is exposed to.

Beside the above-explained economic factors, a standard model of non-life insurance demand usually includes risk aversion, frequency of loss, and institutional determinants. In accordance with the utility theory, risk aversion is positively correlated to the demand for non-life insurance. Higher risk aversion implies less willingness to accept the risk and more incentive to transfer the risk to insurance companies. Since it is difficult to measure the attitude to risk at the macro level, education is usually used as a measure of risk aversion. People with a higher level of education are more risk averse and demand more insurance. When education is taken as a measure of financial literacy, it is expected that individuals with a higher level of education are more risk aware, have more knowledge of insurance products and consequently demand more insurance. On the other hand, more educated and more skilled people have more knowledge on how to manage risk and they are more willing to take self-insurance, which reduces the demand for coverage provided by insurance companies (Outreville, 2013). Additionally, people who are more educated have a higher income, are more able to cover losses by themselves or can afford insurance. Esho et al. (2004) find positive but not significant effect of risk aversion (measured by education and uncertainty avoidance index) 
on the demand for property-liability insurance in cross-sectional estimation and a positive and statistically significant impact of risk aversion, proxied by education, on property-liability consumption in panel data estimation, using the fixed-effect model. According to the findings by Dragos (2014), risk aversion measured by education positively affects the demand for non-life insurance in emerging markets. A positive impact of education is confirmed by Trinh et al. (2016) on a sample of developing countries, while the findings for developed countries are conflicting as non-life insurance markets are mature in those countries. Browne et al. (2000) find a negative influence of risk aversion on the demand for general liability insurance and no significant impact of the risk aversion on motor vehicle insurance demand. A negative effect of risk aversion on insurance demand is also found in studies on the determinants of microinsurance (for literature review see Eling et al. (2013)).

Higher frequency of loss implies higher risk. Thus, it is expected that with a higher probability of loss occurrence, the demand for insurance coverage increases. Since the probability of loss is greater in urban areas (property damage, thefts, car accidents) in comparison to rural ones, the level of urbanization is often used as a proxy of loss frequency in research on determinants of non-life insurance demand (Esho et al., 2004). The probability of loss is confirmed as a determinant of demand for property-liability insurance (Esho et al., 2004). Dragos (2014) finds the same results for emerging markets. A research by Trinh et al. (2016) confirmed a significant positive impact of urbanization on non-life insurance demand in developing countries. However, when considering developed countries, urbanization negatively affects non-life insurance demand, which the authors explain by the mature stage of insurance markets in these countries. In this research, the frequency of loss is measured by the number of cars. The same measure captures the insurance market structure since third-party motor liability insurance is compulsory and car insurance is very common. Consequently, these lines of insurance have a significant share in the total non-life insurance market in many countries. The significant influence of the number of cars on non-life insurance demand is confirmed by Feyen (2011), Kjosevski and Petkovski (2015) and Poposki et al. (2015).

A higher level of financial development, especially the development of banking sector, could increase the customers' trust in the financial system, positively contributing to the demand for non-life insurance. Moreover, it is expected that a more developed financial system reduces transaction costs and consequently, increases the demand for financial services and, among them, the demand for nonlife insurance. Additionally, more loans for housing and cars increase the need for insuring assets. Outreville (1990) and Feyen et al. (2011) show the importance of financial development, defined by private credit to GDP, for non-life insurance demand. The same results are found by Trinh et al. (2016) for the whole sample 
of developed and developing countries as well as for the subsample of developing countries, while the results for developed ones are ambiguous.

Legal environment could be an important prerequisite for the protection of policyholders, increasing confidence in the insurance sector and consequently, the demand for insurance. According to Nakata and Sawada (2007), a low level of contract enforceability makes formal insurance more expensive in comparison to the informal one, which reduces the demand for insurance. A stronger protection of property rights and enforcement of legal rights encourage people to buy insurance coverage of their property. Browne et al. (2000) analyse the impact of the legal system on the demand for motor vehicles and general liability insurance and confirm that these types of insurance are more developed in countries with common-law system in comparison to the countries with statutory-law systems. Esho et al. (2004) and Feyen et al. (2011) show that the enforcement of legal rights positively affects the demand for property-liability insurance. Contract enforceability is also confirmed as a factor of non-life insurance demand by Nakata and Sawada (2007). Kjosevski and Petkovski (2015) find a positive effect of property right protection, measured by the rule of law, on the demand for non-life insurance while no significant effect is found by Poposki et al. (2015).

\section{Data and Methodology}

The impact of financial literacy on the demand for non-life insurance is examined on the dataset of 38 European countries in the period from 2010 to 2016. The selection of countries included in the dataset (Table 1D in the appendix) and variables (Table 1) is determined by data availability. The research is based on a panel analysis that, besides spatial, also encompasses the time component.

Financial literacy is approximated by the percentage of tertiary education graduates completing business, administration and law programmes. This measure of financial literacy is more precise in comparison to the secondary or tertiary education in general, which are the measures commonly used in the existing studies on insurance demand. The new proxy more accurately indicates the specific knowledge of insurance products than the general level of education. Namely, since insurance combines both financial and legal concepts, this measure is more appropriate to express financial/insurance literacy. Other variables, measures, data sources, and expected impact of the variables are presented in Table 1. 


\section{Table 1}

DEFINITION, SOURCE AND EXPECTED IMPACT OF THE VARIABLES

\begin{tabular}{|c|c|c|c|c|}
\hline Variable & Variable measure & \begin{tabular}{|c|}
$\begin{array}{c}\text { Variable } \\
\text { code }\end{array}$ \\
\end{tabular} & Data source & $\begin{array}{c}\text { Expected } \\
\text { impact }\end{array}$ \\
\hline $\begin{array}{l}\text { Non-life } \\
\text { insurance } \\
\text { demand }\end{array}$ & $\begin{array}{l}\text { The ratio of total gross } \\
\text { premiums written for } \\
\text { non-life insurance to total } \\
\text { GDP (current prices) }\end{array}$ & INS & $\begin{array}{l}\text { World Bank, } \\
\text { Financial } \\
\text { Structure Database }\end{array}$ & $\begin{array}{l}\text { Dependent } \\
\text { variable }\end{array}$ \\
\hline $\begin{array}{l}\text { Financial } \\
\text { literacy }\end{array}$ & $\begin{array}{l}\text { Percentage of graduates } \\
\text { from tertiary education } \\
\text { graduating from business, } \\
\text { administration and } \\
\text { law programmes, both } \\
\text { sexes }(\%)\end{array}$ & FINLIT & $\begin{array}{l}\text { OECD, OECD } \\
\text { Statistics }\end{array}$ & + \\
\hline Income & $\begin{array}{l}\text { GDP per capita } \\
\text { (current US\$) }\end{array}$ & INCOME & $\begin{array}{l}\text { World Bank, } \\
\text { national accounts } \\
\text { data, and OECD } \\
\text { National Accounts } \\
\text { data files }\end{array}$ & $+/-$ \\
\hline Inflation & $\begin{array}{l}\text { Inflation, GDP deflator } \\
(\text { annual \%) }\end{array}$ & INFLN & $\begin{array}{l}\text { World Bank, } \\
\text { International } \\
\text { Monetary Fund, } \\
\text { International } \\
\text { Financial Statistics }\end{array}$ & - \\
\hline Risk aversion & $\begin{array}{l}\text { Labour force with } \\
\text { intermediate education } \\
\text { (\% of total working- } \\
\text { age population with } \\
\text { intermediate education) }\end{array}$ & RISK_AV & $\begin{array}{l}\text { World Bank, } \\
\text { UNESCO Institute } \\
\text { for Statistics }\end{array}$ & $+/-$ \\
\hline $\begin{array}{c}\text { Probability of } \\
\text { loss/Market } \\
\text { structure }\end{array}$ & $\begin{array}{l}\text { Passenger road vehicle } \\
\text { fleet and rate per thousand } \\
\text { inhabitants }\end{array}$ & PROB & United Nations & + \\
\hline $\begin{array}{c}\text { Financial } \\
\text { development }\end{array}$ & $\begin{array}{l}\text { Domestic credit to private } \\
\text { sector by banks } \\
(\% \text { of GDP) }\end{array}$ & FINDEV & $\begin{array}{l}\text { International } \\
\text { Monetary Fund, } \\
\text { International } \\
\text { Financial } \\
\text { Statistics, World } \\
\text { Bank and OECD }\end{array}$ & + \\
\hline
\end{tabular}




\begin{tabular}{|c|l|c|l|c|}
\hline Variable & \multicolumn{1}{|c|}{ Variable measure } & $\begin{array}{c}\text { Variable } \\
\text { code }\end{array}$ & Data source & $\begin{array}{c}\text { Expected } \\
\text { impact }\end{array}$ \\
\hline Economic \\
Freedom & $\begin{array}{l}\text { The index of Economic } \\
\text { Freedom is a method } \\
\text { of scoring and ranking } \\
\text { jurisdictions based on } \\
\text { the degree of economic } \\
\text { freedom (judged by } \\
\text { factors such as rule of law, } \\
\text { property rights, tax and } \\
\text { regulation) }\end{array}$ & $\begin{array}{c}\text { PROP_ } \\
\text { RIGHTS }\end{array}$ & $\begin{array}{l}\text { Heritage } \\
\text { Foundation }\end{array}$ & + \\
\hline
\end{tabular}

Source: Created by the authors.

Data that refer to disposable income (INCOME), frequency of an insured event (PROB) and economic freedom assessment (PROP_RIGHTS) are transformed by taking their natural logarithms. Data expressed in percentage, such as the ratio of total gross premiums written for non-life insurance to total GDP (INS), the percentage of graduates from tertiary education graduating in business, administration and law (FINLIT), labour force with secondary education as a percentage of the total working-age population (RISK_AV), GDP deflator (\% annual) (INFLN), domestic credit to the private sector by banks (\% of GDP) (FINDEV), are not transformed, since they are already in the required form as a measure of change (Zerriaa and Noubbigh, 2016).

Table 2

SUMMARY STATISTICS

\begin{tabular}{|l|c|c|c|c|c|c|}
\hline Variable & Mean & Std. Dev. & Maximum & Minimum & $\begin{array}{c}\text { Number of } \\
\text { countries }\end{array}$ & $\begin{array}{c}\text { Observa- } \\
\text { tions }\end{array}$ \\
\hline INS & 1.56 & 0.52 & 0.47 & 2.78 & 38 & 260 \\
\hline FINLIT & 26.91 & 7.48 & 12.91 & 48.18 & 38 & 210 \\
\hline INCOME & 9.89 & 1.00 & 7.40 & 11.69 & 38 & 266 \\
\hline INFLN & 2.42 & 3.95 & -3.22 & 38.88 & 38 & 266 \\
\hline RISK_AV & 58.87 & 7.95 & 32.55 & 74.66 & 38 & 248 \\
\hline PROB & 5.95 & 0.47 & 4.62 & 6.51 & 38 & 250 \\
\hline FINDEV & 86.59 & 46.87 & 26.66 & 253.15 & 38 & 266 \\
\hline PROP_RIGHTS & 4.18 & 0.22 & 3.00 & 4.55 & 38 & 266 \\
\hline
\end{tabular}

Source: Created by the authors. 
Table 2 contains descriptive statistics. Mean value of non-life insurance demand measured by penetration for all countries in the sample is 1.56 percent. The standard deviation of insurance penetration amounts to 0.52 percentage points.

According to Hsiao (2005), panel data contain inter-individual differences and intra-individual dynamics, which impose an advantage over cross-sectional or time-series data. The advantage is reflected in the more accurate inference of model parameters. Furthermore, panel data reduce estimator bias, while simultaneously reducing the problems of data multicollinearity (Hsiao, 1985).

The model of non-life insurance demand follows.

$$
\begin{gathered}
\mathrm{INS}_{i, t}=\alpha+\gamma \mathrm{INS}_{i, t-1}+\beta_{1} \mathrm{FINLIT}_{i, t}+\beta_{2} \mathrm{X}_{i, t}+\cdots+\beta_{K} \mathrm{X}_{i, t, K}+\mu_{i}+\varepsilon_{i, t} \\
i=1,2, \ldots, N, t=1,2, \ldots, T, K=7
\end{gathered}
$$

Where:

$\mathrm{N} \quad-\quad$ the number of observation units, a total of 38 countries,

$\mathrm{T} \quad-\quad$ the period of observation, the observed period is 7 years $(2010$ 2016),

$\mathrm{K} \quad-\quad$ the number of explanatory variables of the model,

$\mu \quad-$ constant,

$\alpha_{i} \quad-$ an unobserved country-specific effect,

$\varepsilon_{i,} \quad-\quad$ error term and the subscripts $i$ and $t$ represent country and time period respectively,

$\gamma \quad-\quad$ lagged dependent variable parameter,

$\beta_{1}, \ldots, \beta_{\mathrm{K}}-$ explanatory variable parameters, where $K=7$ represents the number of explanatory variables

$\mathrm{X}_{3} \ldots \mathrm{X}_{\mathrm{K}}-$ a set of control variables,

$\mathrm{INS}_{i, t-1} \quad-$ non-life insurance demand indicator in the country $i$ and for the period $t$-1,

FINLIT $_{i, t}$ - the indicator of financial literacy in the country $i$ and for the period $t$.

In addition to new insurance contracts, the demand for non-life insurance is also determined by the contracted insurance policies in the previous period. This requires an autoregressive model, which implies the inclusion of the lagged dependent variable as an explanatory determinant (Baltagi, 2008). Further, the validity of the use of a dynamic panel model derives from a theory that explains the possible existence of a mutual causation between non-life insurance demand (INS) and disposable income (INCOME). Namely, if non-life insurance demand can be explained by changes in disposable income and at the same time it is a valid 
notion of mutual causality then the variable disposable income becomes correlated with a random error. It is known as a problem of endogeneity, which results in heteroscedasticity (Wooldridge, 2009). According to Baltagi (2008), the dynamic panel model efficiently solves the problem of endogeneity. Therefore, disposable income (INCOME) is treated as an endogenous variable.

The Blundell-Bond (BB) estimator is used in the analysis. The selection is based on the sample characteristics. The number of observation units (countries) is greater than the number of periods, thus meeting the condition of the BlundellBond (BB) estimator (Škrabić Perić, 2012). The estimator is used in two steps because it is robust to heteroscedasticity and is a more efficient estimator (Blundell and Bond, 1998).

According to Baltagi (2008), panel analysis does not presuppose a multicollinearity test, hence the possible multicollinearity problem is analysed by the correlation matrix (Table 3 ).

Table 3

\section{CORRELATION MATRIX}

\begin{tabular}{|l|c|c|c|c|c|c|c|}
\hline & FINLIT & INCOME & INFLN & RISK_AV & PROB & FINDEV & $\begin{array}{c}\text { PROP_ } \\
\text { RIGHTS }\end{array}$ \\
\hline FINLIT & 1 & & & & & & \\
\hline INCOME & -0.41 & 1 & & & & & \\
\hline INFLN & 0.23 & -0.43 & 1 & & & & \\
\hline RISK_AV & -0.37 & 0.5 & -0.22 & 1 & & & \\
\hline PROB & -0.36 & 0.79 & -0.5 & 0.48 & 1 & & \\
\hline FINDEV & -0.15 & 0.6 & -0.32 & 0.51 & 0.49 & 1 & \\
\hline $\begin{array}{l}\text { PROP_ } \\
\text { RIGHTS }\end{array}$ & -0.23 & 0.6 & -0.61 & 0.52 & 0.51 & 0.43 & 1 \\
\hline
\end{tabular}

Source: Created by the authors.

Table 3 contains Pearson correlation coefficients between explanatory variables. A pronounced correlation is noticed between frequency of loss (PROB) and disposable income (INCOME). However, Gujarati and Porter (2009) noticed that a correlation coefficient implies serious multicollinearity when the absolute value of coefficient exceeds 0.8 . 


\section{Results}

Table 4 represents the results of estimation of the non-life insurance demand model by applying the Blundell-Bond estimator. According to Roodman (2009), Sargan test is valid in the case when the number of instruments does not exceed the number of observation groups, what is fulfilled. The validity of each model is tested by Sargan test. The test confirms that there is no endogeneity problem. Another diagnostic test refers to autocorrelation of residuals (first-order serial correlation and second-order serial correlation). The residual autocorrelation test confirms the consistency of the estimator.

In line with the expectations, the coefficients of variable financial literacy in all model specifications are positive and statistically significant, implying the importance of understanding risk and knowledge of the insurance concept for making a decision to buy insurance. This result confirms the importance of educational efforts by academia and insurance industry to increase the demand for non-life insurance.

Disposable income is the most important determinant of non-life insurance demand and the coefficient's sign is in line with theoretical expectations and the results of previous empirical research (Beenstock et al., 1988; Outreville, 1990; Esho et al., 2004; Feyen et al., 2011; Elango and Jones, 2011; Poposki et al., 2015; Trinh et al., 2016). With a higher level of disposable income, there is a greater demand for insurance.

The impact of the following economic factor, i.e. inflation, on the demand for non-life insurance is in line with the expectations. There is a negative relationship between inflation and non-life insurance. The monetary instability reduces the compensation for loss and individuals are less willing to buy insurance. A research by Poposki et al. (2015) produced the same results.

The estimation's results confirm a positive influence of risk aversion. Thus, a higher degree of risk aversion reduces the willingness to retain the risk and increases insurance consumption. The result is in line with Dragos (2014) for the sample of emerging markets.

The frequency of loss, measured by the number of cars per thousand residents $^{3}$, is confirmed as statistically significant and has a positive impact on the decision to purchase non-life insurance. This is also a proxy of non-life insurance structure and indicates the importance of motor third-party liability insurance and

${ }^{3}$ Beside the number of cars per thousand residents, the level of urbanization was applied as measure of frequency of loss as well. However, the result was statistically insignificant. 
M. ĆURAK, S. PEPUR, D. KOVAČ: Does financial literacy make the difference in non-life insurance demand..

EKONOMSKI PREGLED, 71 (4) 359-381 (2020)

car insurance. The same result is found by Feyen et al. (2011), Kjosevski and Petkovski (2015) and Poposki et al. (2015).

Table 4

THE RESULTS OF THE PANEL DATA ANALYSIS FOR MODELS OF NON-LIFE INSURANCE DEMAND

\begin{tabular}{|c|c|c|c|}
\hline & $\begin{array}{c}\text { Model_BB_1 } \\
\text { INS }\end{array}$ & $\begin{array}{c}\text { Model_BB_2 } \\
\text { INS }\end{array}$ & $\begin{array}{c}\text { Model_BB_3 } \\
\text { INS }\end{array}$ \\
\hline L.INS & $\begin{array}{l}0.699^{* * *} \\
-0.028\end{array}$ & $\begin{array}{l}0.674^{\text {*** }} \\
-0.0311\end{array}$ & $\begin{array}{c}0.696^{* * *} \\
-0.0288\end{array}$ \\
\hline FINLIT & $\begin{array}{l}0.00295^{* *} \\
-0.00134\end{array}$ & $\begin{array}{l}0.00405^{* * *} \\
-0.00146\end{array}$ & $\begin{array}{c}0.00316^{* *} \\
-0.00138\end{array}$ \\
\hline INCOME & $\begin{array}{c}0.168^{* * * *} \\
-0.0159\end{array}$ & $\begin{array}{c}0.149^{* * *} \\
-0.0188\end{array}$ & $\begin{array}{l}0.164^{* * *} \\
-0.033\end{array}$ \\
\hline INFLN & $\begin{array}{l}-0.0141^{* * *} \\
-0.00112\end{array}$ & $\begin{array}{l}-0.0157^{* * *} \\
-0.00126\end{array}$ & $\begin{array}{l}-0.0137^{\text {**** }} \\
-0.00123\end{array}$ \\
\hline RISK_AV & $\begin{array}{l}0.00690^{* * *} \\
-0.00194\end{array}$ & $\begin{array}{c}0.00388^{*} \\
-0.00199 \\
\end{array}$ & $\begin{array}{l}0.00729^{* * * *} \\
-0.00183\end{array}$ \\
\hline PROB & $\begin{array}{l}0.0902^{* * * *} \\
-0.0336\end{array}$ & $\begin{array}{l}0.128^{* * *} \\
-0.024\end{array}$ & $\begin{array}{c}0.104^{* * * *} \\
-0.0302 \\
\end{array}$ \\
\hline FINDEV & & $\begin{array}{c}0.000810^{\text {**** }} \\
-0.000253\end{array}$ & \\
\hline PROP_RIGHTS & & & $\begin{array}{l}0.0736 \\
-0.175 \\
\end{array}$ \\
\hline _cons & $\begin{array}{l}-2.237^{\text {*** }} \\
-0.245\end{array}$ & $\begin{array}{l}-2.150^{* * *} \\
-0.254\end{array}$ & $\begin{array}{l}-2.619^{\text {**** }} \\
-0.522\end{array}$ \\
\hline $\begin{array}{c}\text { Number of } \\
\text { observations }\end{array}$ & 187 & 187 & 187 \\
\hline Number of countries & 38 & 38 & 38 \\
\hline $\begin{array}{c}\text { Sargan's test } \\
\text { (p-value) }\end{array}$ & 0.3241 & 0.2418 & 0.3245 \\
\hline m1 (p-value) & 0.017 & 0.0146 & 0.0169 \\
\hline m2 (p-value) & 0.7881 & 0.5015 & 0.7725 \\
\hline
\end{tabular}

Notes: $* \mathrm{p}<0.1, * * \mathrm{p}<0.05, * * * \mathrm{p}<0.01$

Source: Created by the authors. 
Non-life insurance demand is positively affected by financial development, which is in line with theoretical expectations and the results of empirical research by Outreville (1990), Feyen et al. (2011) and Trinh et al. (2016). Thus, a higher level of banking sector development increases trust in the financial sector in general and insurance sector in particular. Moreover, the availability of loans increases purchasing of houses and cars, encouraging the demand for insurance coverage.

The institutional environment, measured by the index of economic freedom, does not confirm the statistically significant impact on non-life insurance demand.

\section{Conclusion}

The paper analysed the impact of financial literacy on non-life insurance, while controlling for the influence of other important determinants on non-life insurance demand. The empirical research was based on a panel dataset of 38 European countries in the period from 2010 to 2016 and the dynamic panel estimator. The research findings confirmed a positive contribution of financial literacy to non-life insurance demand. Thus, the educational efforts to increase financial literacy are important for non-life insurance consumption. Other important determinants are risk aversion, probability of loss, income, inflation, and financial development. With the exception of monetary instability, all the factors positively affect the demand for non-life insurance. This is in line with the results of most of the existing studies. Contrary to theoretical expectations and the results of some previous empirical studies, legal environment is not confirmed as a determinant of non-life insurance purchase.

The findings are useful for the academia, insurance companies, and policymakers. High schools and higher education institutions should continue improving study programmes by transferring knowledge on insurance contracts and insurance issues, which are less included in the existing programmes in comparison to other financial issues. Beside regular study programmes, insurance can also be taught at courses which are a part of the lifelong learning programmes. In this way, financial literacy, which is an important aspect of human capital related to managing personal finance, would be more developed. Insurance companies and associations of insurers as well as insurance distributors could also put in additional effort to achieve a higher level of financial literacy by organizing training activities and courses for customers as a means of providing them with information and advice. This especially refers to the terms of insurance contracts. These efforts could additionally develop the trust of both existing and potential policyholders in the insurance industry, which would be valuable for insurance companies in their 
servicing the existing insurance markets and entering new ones, with the effect of increasing the demand for insurance and growth of insurance markets. In order to contribute to the development of non-life insurance market, policymakers should ensure sound economic and financial environments as well as monetary stability.

The study has some limitations. Non-life insurance products are heterogeneous in terms of the risks they cover. However, due to data availability limitation it was not possible to analyse the demand for particular non-life products. Owing to the same reason, the time span is relatively short.

By extending PISA database with longer time series, additional proxies for financial literacy will be available for a future cross-country research on non-life insurance demand. Considering the very heterogeneous structure of non-life insurance products, forthcoming research on non-life insurance demand could focus on specific line of non-life insurance. Additionally, taking into consideration the difference in the insurance development between Western on the one side and Central and Eastern European countries on the other, a suggestion for future research is to investigate if there is a difference in the determinants of a specific line of non-life insurance demand between these two groups of countries.

\section{References}

1. Baltagi, B.H. (2008). Econometric Analysis of Panel Data. Chester: John Wiley and Sons.

2. Barbić, D. and Glasnović, E. (2018). Uloga različitih izvora financijskog obrazovanja u stvaranju financijski pismenih građana. In Brečić, R. and Filipović, J. (Ed.), Financijska pismenost i socijalizacija djece kao potrošača. Zagreb: Ekonomski fakultet Zagreb, Sveučilišna tiskara d.o.o.

3. Beenstock, M., Dickinson, G. and Khajuria, S. (1988). The Relationship between Property-Liability Insurance Premiums and Income: An International Analysis. Journal of Risk and Insurance, 55(2), 259-272. DOI:10.2307/253327.

4. Blundell, R., Bond, S. (1998). Initial conditions and moment restrictions in dynamic panel data models. Journal of Econometrics, 87(1), 115-143. DOI: 10.1016/S0304-4076(98)00009-8.

5. Browne, M. J., Chung, J. W. and Frees, E. W. (2000). International PropertyLiability Insurance Consumption. The Journal of Risk and Insurance, 67(1), 73-90. DOI:10.2307/253677. 
6. Cappelletti, G., Guazzarotti, G. and Tommasino, P. (2013). What determines annuity demand at retirement?. The Geneva Papers on Risk and InsuranceIssues and Practice 38(4), 777-802. DOI: 10.1057/gpp.2012.43.

7. Dragos, S. L. (2014). Life and non-life insurance demand: the different effects of influence factors in emerging countries from Europe and Asia. Economic Research-Ekonomska istraživanja, 27(1), 169-180. DOI: 10.1080/1331677X.2014.952112.

8. Elango, B. and Jones, J. (2011). Drivers of Insurance Demand in Emerging Markets. Journal of Service Science Research, 3 (2), 185-204. DOI: 10.1007/ s12927-011-0008-4.

9. Eling, M., Pradhan, S. and Schmit, J. T. (2013). The Determinants of Microinsurance demand. The Geneva Papers on Risk and Insurance - Issues and Practice, 39(2), 224-263. DOI: 10.2139/ssrn.2279355.

10. Esho, N., Kirievsky, A., Ward, D. and Zurbruegg, R. (2004). Law and the determinants of Property-Casualty insurance. Journal of Risk and Insurance, 71(2), 265-283. DOI: 10.1111/j.0022-4367.2004.00089.x.

11. Feyen, E., Lester, R. and Rocha, R. (2011). What Drives the Development of the Insurance Sector. Policy Research Working Paper, No. 5572, World Bank, Washington. Available at: http://hdl.handle.net/10986/3339. Accessed: May 31, 2019.

12. Gousia, K. (2016). Financial literacy and long-term care insurance coverage. SHARE Working Paper Series, No. 26-2016. Available at: http://www.shareproject.org/uploads/tx_sharepublications/WP_Series_26_2016_Gousia.pdf. Accessed: May 26, 2019.

13. Gujarati, D. N., Porter, D. C. (2009). Basic Econometrics. 4th ed. Irwin/McGraw-Hill.

14. Hecht, C. and Hanewald, K. (2010). Sociodemographic, economic, and psychological drivers of the demand for life insurance: Evidence from the German retirement income act. SFB 649 Humboldt-Universität Discussion Paper No. 2010-034. DOI: 10.18452/4262.

15. Hsiao, C. (1985). Benefits and limitations of panel data. Econometric Reviews, 4(1), 121-174. DOI: 10.1080/07474938508800078.

16. Hsiao, C. (2005). Why panel data?. The Singapore Economic Review, 50(2), 143-154. DOI: 10.2139/ssrn.820204.

17. Insurance Europe (2017). Financial Education in a Digital Age, Initiatives by the European insurance industry, 3/2017. Available at: https://www.insuranceeurope.eu/sites/default/files/attachments/Financial\%20education\%20 in\%20a\%20digital\%20age.pdf. Accessed: May 31, 2019. 
18. Jappelli, T. (2010). Economic literacy: An International Comparison. The Economic Journal, 120 (548), 429-451. DOI:10.1111/j.1468-0297.2010.02397.x.

19. Kjosevski J. and Petkovski, M. (2015). The Determinants of Non-Life Insurance Consumption: A VECM Analysis in Central and South-Eastern Europe. Acta Oeconomica, 65 (1), 107-127. DOI: 10.1556/AOecon.65.2015.1.6.

20. Kubitza, C., Hofmann, A. and Steinorth, P. (2019). Financial Literacy and Precautionary Insurance. Available at: https://ssrn.com/abstract=3346477. Accessed: May 25, 2019.

21. Lin, H. and Prince, J. T. (2016). Determinants of Private Long-Term Care Insurance Purchase in Response to the Partnership Program. Health Service Research, 51(2), 687-703., DOI: 10.1111/1475-6773.12353. DOI: 10.1111/14756773.12353.

22. Lin, X., Bruhn, A., and William, J. (2019). Extending financial literacy to insurance literacy: a survey approach. Accounting and Finance, 59(S1), 685713. DOI: $10.1111 /$ acfi.12353.

23. Lusardi, A. and Mitchell, O. S. (2011). Financial Literacy Around the World: An Overview, Journal of Pension Economics and Finance, 10(4), 497 - 508. DOI: $10.1017 /$ S1474747211000448

24. Lusardi, A. and Mitchell, O.S. (2014). The Economic Importance of Financial Literacy: Theory and Evidence. Journal of Economic Literature, 52(1), 5-44. DOI: $10.3386 / \mathrm{w} 18952$.

25. Marquis, M. S., Buntin, M. B., Escarce, J. J., Kapur, K., and Yegian, J. M. (2004). Subsidies and the demand for individual health insurance in California. Health Services Research, 39(5), 1547-1566. DOI: 10.1111/j.14756773.2004.00303.x.

26. Nakata, H. and Sawada, Y. (2007). The Demand for Non-Life Insurance: A Cross-Country Analysis. Unpublished Manuscript, University of Essex. Available at: https://core.ac.uk/download/pdf/6341545.pdf. Accessed: May 31, 2019.

27. OECD (2005). Improving Financial Literacy: Analysis of Issues and Policies. Paris: OECD. DOI:10.1787/fmt-v2005-art11-en.

28. Outreville, J. F. (1990). The Economic Significance of Insurance Markets in Developing Countries. Journal of Risk and Insurance, 57(3), 487-498. DOI: $10.2307 / 252844$.

29. Outreville, J. F. (2013). The relationship between insurance growth and economic development - 80 empirical papers for a review of the literature. Risk Management and Insurance Review, 16(1), 71-122. DOI: 10.1111/j.15406296.2012.01219.x.

30. Poposki, K., Kjosevski, J. and Stojanovski, Z. (2015). The determinants of non-life insurance penetration in selected countries from South Eastern 
Europe. Economics and Business Review, 1(15), 3, 20-27. DOI: 10.18559/ ebr.2015.3.3.

31. Roodman, D. (2009). A note on the theme of too many instruments. $O x$ ford Bulletin of Economics and Statistics, 71(1), 35-158. DOI: 10.2139/ ssrn.1101731.

32. Škrabić Perić, B. (2012). Utjecaj stranog vlasništva banke na njezin kreditni rizik u zemljama srednje i istočne Europe: dinamički panel modeli. PhD Thesis. Split: Ekonomski fakultet.

33. Swiss Re (2018) World insurance in 2017: solid, but mature life markets weigh on growth. Sigma, 3/2018. Available at: https://www.swissre.com/institute/research/sigma-research/sigma-2018-03.html. Accessed: May 31, 2019.

34. Tennyson, S. (2011a) Insurance Literacy: Evidence from Survey Data. Financial Services Review, 20, 165-179.

35. Tennyson, S. (2011b). Consumers' Insurance Literacy. Networks Financial Institute, at Indiana State University, 2011-PB-06. Available at: https://ssrn.com/ abstract=1896316. Accessed: May 31, 2019.

36. Treerattanapun, A. (2011). The impact of culture on non-life insurance consumption. Wharton Research Scholars, 5-13-2011, The University of Pennsylvania. Available at: http://repository.upenn.edu/wharton_research_scholars/78. Accessed: May 31, 2019.

37. Trinh, T., Nguyen, X. and Sgro, P. (2016). Determinants of non-life insurance expenditure in developed and developing countries: an empirical investigation. Applied Economics, 48 (58), 5639-5653. DOI: 10.1080/00036846.2016.1181834.

38. Vehovec, M. (2011). Financijska i mirovinska pismenost: međunarodna iskustva i prijedlozi za Hrvatsku. Privredna kretanja i ekonomska politika, 21(126), 65-85. Available at: https://hrcak.srce.hr/index.php?show=clanak\&id_clanak_jezik=115362. Accessed: April 23, 2019.

39. Wooldridge, J. M. (2009). Introductory Econometrics: A Modern Approach, 5th ed., Australia, Nelson Education.

40. Zerriaa, M., Noubbigh, H. (2016). Determinants of Life Insurance Demand in the MENA Region. The Geneva Papers on Risk and Insurance - Issues and Practice, 41(3), 1-21. DOI: 10.1057/gpp.2016.1. 


\title{
APPENDIX
}

Table 1D

LIST OF COUNTRIES

\begin{tabular}{|l|l|l|l|}
\hline \multicolumn{1}{|c|}{ Country } & \multicolumn{1}{c|}{ Country } & \multicolumn{1}{c|}{ Country } & \multicolumn{1}{c|}{ Country } \\
\hline Albania & Finland & Luxembourg & Slovak Republic \\
\hline Austria & France & North Macedonia & Slovenia \\
\hline Belgium & Georgia & Malta & Spain \\
\hline $\begin{array}{l}\text { Bosnia and } \\
\text { Herzegovina }\end{array}$ & Germany & Moldova & Sweden \\
\hline Bulgaria & Greece & Netherlands & Switzerland \\
\hline Croatia & Hungary & Norway & Turkey \\
\hline Cyprus & Ireland & Poland & Ukraine \\
\hline Czech Republic & Italy & Portugal & United Kingdom \\
\hline Denmark & Latvia & Russian Federation & \\
\hline Estonia & Lithuania & Serbia & \\
\hline
\end{tabular}

Source: Created by the authors.

\author{
STVARA LI FINANCIJSKA PISMENOST RAZLIKE U POTRAŽNJI \\ ZA NEŽIVOTNIM OSIGURANJIMA MEĐU EUROPSKIM ZEMLJAMA?
}

\section{Sažetak}

Dok su averzija prema riziku i dohodak uobičajeno razmatrane kao najvažnije odrednice potražnje za neživotnim osiguranjem, razumijevanje i znanje o složenim proizvodima neživotnog osiguranja manje su istraživani. Istraživanja o potražnji za osiguranjem na „,cross-section“ razini, a koje obuhvaćaju obrazovanje, uobičajeno ga koriste za aproksimiranje averzije prema riziku i, samo u određenoj mjeri, za financijsku pismenost. Štoviše, opća razina obrazovanja nedovoljno odražava razumijevanje sofisticiranih instrumenata osiguranja. Stoga je glavni cilj ovoga istraživanja analizirati utjecaj financijske pismenosti na potražnju za neživotnim osiguranjem primjenjujući precizniju mjeru financijske pismenosti. Empirijska analiza je bazirana na podacima 38 europskih zemalja u razdoblju od 2010. do 2016. i tehnici panel analize. Rezultati istraživanja potvrđuju da financijska pismenost stvara razlike u potražnji za neživotnim osiguranjem među europskim zemljama, uz istodobno uvažavanje ostalih ekonomskih, socijalno/kulturoloških te institucionalnih čimbenika, kao i onih vezanih za strukturu tržišta. Rad doprinosi literaturi u području potražnje za neživotnim osiguranjem, posebno u dijelu koji se odnosi na vezu između financijske pismenosti i potražnje za neživotnim osiguranjem.

Ključne riječi: Financijska pismenost, neživotno osiguranje, europske zemlje 